\title{
Comparative study of abdominal cavity temporary closure techniques for damage control
}

\section{Estudo comparativo de técnicas de fechamento temporário da cavidade abdominal durante o controle de danos}

Marcelo A. F. Ribeiro Jr, TCBC-SP1; Emily Alves Barrosi; Sabrina Marques de Carvalho'; Vinicius Pereira Nascimento ; José CruVinel Neto, TCBC-SP1; AleXandre Zanchenko Fonseca'.

\section{A B S T R A C T}

\begin{abstract}
The damage control surgery, with emphasis on laparostomy, usually results in shrinkage of the aponeurosis and loss of the ability to close the abdominal wall, leading to the formation of ventral incisional hernias. Currently, various techniques offer greater chances of closing the abdominal cavity with less tension. Thus, this study aims to evaluate three temporary closure techniques of the abdominal cavity: the Vacuum-Assisted Closure Therapy - VAC, the Bogotá Bag and the Vacuum-pack. We conducted a systematic review of the literature, selecting 28 articles published in the last 20 years. The techniques of the bag Bogotá and Vacuum-pack had the advantage of easy access to the material in most centers and low cost, contrary to VAC, which, besides presenting high cost, is not available in most hospitals. On the other hand, the VAC technique was more effective in reducing stress at the edges of lesions, removing stagnant fluids and waste, in addition to acting at the cellular level by increasing proliferation and cell division rates, and showed the highest rates of primary closure of the abdominal cavity.
\end{abstract}

Keywords: Abdomen. Peritonitis. Wounds and Injuries. Abdominal Wall. Infection.

\section{INTRODUCTION}

nitially, the surgical principles in the abdominal trauma approach were based on anatomical repairs aimed at primary and final organic repair. In the last decade, more importance was given to correct the physiological problems, leading to the concept of damage control surgery, with special emphasis on maintaining the abdomen open through laparostomy, or peritoneostomy' . It represents a way to treat the physiological exhaustion and to postpone some procedures that, when performed at the first operative time, only lead to worsening of the patient's physiological condition, with impossibility of recovery ${ }^{1}$. At this time the scope is to control bleeding and treat contamination of the cavity to stop the lethal trauma triad.

The main indications for laparostomy are the inability to close the abdominal cavity, documented intra-abdominal hypertension, abdominal compartment syndrome, need for drainage of the abdominal cavity by severe infection, need for relaparotomy, coagulopathy, hypothermia $\left(<35^{\circ} \mathrm{C}\right)$ and hemodynamic instability ${ }^{2,3}$.
During the time the abdomen remains open, there is lateral retraction of the aponeurosis, hindering the closure of the cavity and favoring the appearance of incisional hernias. These lead to the formation of adhesions and make future abdominal surgery more complicated, with increased morbidity and mortality ${ }^{4}$. This, however, can be avoided by employing temporary closure techniques such as: Bogotá bag technique, Barker machines (Vacuum -pack) and Vacuum Assisted closure Therapy (VAC) among others, which allow for closure of the abdominal cavity with less tension.

Edelmuth et al. ${ }^{4}$ found that surgery for damage control was efficient in patients with hemodynamic instability due to severe sepsis, massive hemorrhage, acute mesenteric ischemia or necrotizing infections. These factors, together with the need for repeated peritoneal irrigations to eradicate infectious foci and reevaluate sutures and anastomoses, can also be indications for damage control surgery in emergency cases not caused by trauma.

The objective of this study is to compare the three aforementioned temporary closure techniques of

1 - Medicine School, University of Santo Amaro (UNISA), Santo Amaro, SP, Brasil. 
the abdominal cavity after abdominal surgery resulting from trauma, by reviewing the literature on Medline, Pubmed, SciELO and Lilacs, with selection of 28 articles published on the matter over the past 20 years.

\section{DESCRIPTION OF TECHNIQUES}

\section{Bogotá Bag}

It was first described in 1984, when using plastic bags containing parenteral solutions to coat the abdominal opening in a patient in the third surgical intervention ${ }^{5}$. It therefore comprises the use of polyvinyl chloride (plastic bag) for maintaining the abdomen open ${ }^{5}$, through its suture directly to the abdominal wall skin or fascia6. Initially called the Bogotá Bag or Borráez bag (Figure 1), it can be used in combination with a polypropylene mesh as a way of strengthening and restraint, in an attempt to avoid eviscerations and difficulties in mobilizing the patient, which constitute one of the problems arising from this technique?.

The Bogotá technical advantages are: low cost, immediate availability, flexibility and high strength, nonadherence to tissues, absence of allergic or inflammatory reactions and quick and easy installation without the need for major surgical experience ${ }^{5}$. It is also considered an efficient protector against water and heat loss ${ }^{7}$.

It is, however, a procedure which requires increased use of drains and repeated cleansing, presenting risk of evisceration and difficulty in mobilizing the patient ${ }^{8}$.
It can also generate lacerations of the skin, gut adhesion to the abdominal wall, difficulties in reproaching the abdomen and the need for sterilization of the bag before use. Moreover, it allows the output of peritoneal fluids between the bag and the skin.

\section{Vacuum-Pack}

Described in 1995 it uses vacuum dressings for temporary closure of the abdominal cavity and has since been called the "vacum-pack" (VP) or Barker technique ${ }^{9}$. It is low cost and simple ${ }^{10-12}$. It consists in placing a fenestrated polyethylene sheet between the abdominal viscera and the anterior parietal peritoneum, a moist surgical compress on the sheet with two suction drains, and an adhesive sheet over the entire wound including a wide margin surrounding skin. The drains are then connected to a suction device, which can provide $100-150 \mathrm{mmHg}$ continuous negative pressure $^{13}$ (Figure 2).

This technique prevents damage to the abdominal wall by not using sutures, preserving it for future approaches or permanent closure by maintaining the integrity of the fascia for later closing, and allows a quick rapprochement to the abdominal cavity. The material in contact with the abdominal viscera - the polyethylene sheet - is non-adherent, and this technique allows secure control of the amount of fluid produced ${ }^{12}$.

Regarding the primary fascial closure with the use of this technique, in 1997 a study obtained success in $61 \%$ of cases. The patients, who were trauma victims

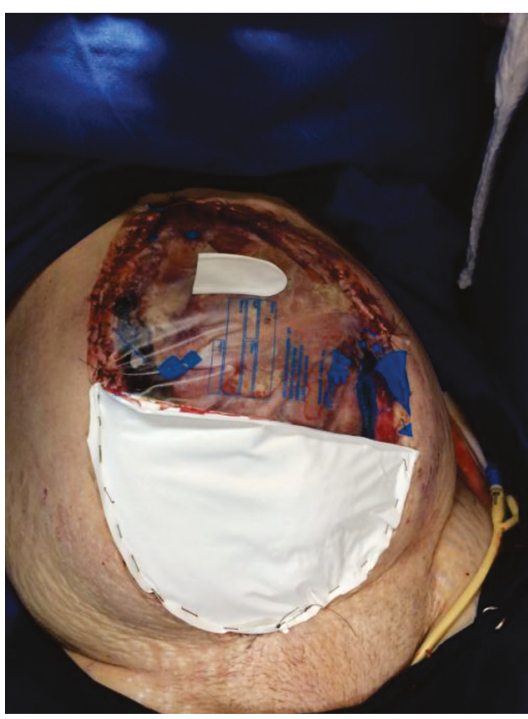

Figure 1. Bogotá bag technique.

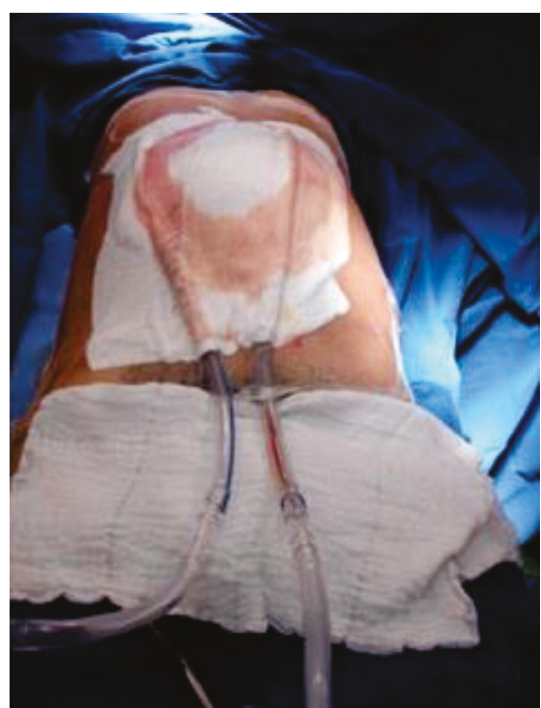

Figure 2. Barker Technique

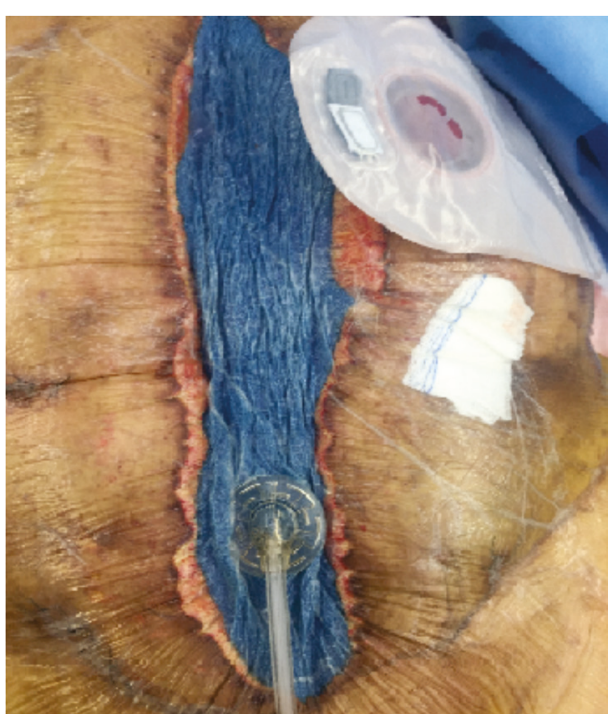

Figure 3. Vaccum - Assited Closure - VAC. 
subjected to the Barker technique, had primary fascial closure at the second laparotomy ${ }^{13}$. Other studies had success rates of $29-100 \%{ }^{11,14-16}$. The permanent closure of the abdominal cavity after the 8th day of laparotomy was associated with higher incidence of complications ${ }^{17}$.

Barker et al. presented their experience using this technique in intestinal lesions undergoing resection, a study that lasted 11 years. There was no difference between patients who used the Barker technique or other techniques in relation to fistulas or anastomotic leaks. Other studies, however, reported fistula rates of $3 \%$ to $5 \%{ }^{14,18,19}$. A combined study of victims of trauma and other causes of open abdomen reported as complications related to the use of this technique: abdominal abscess/ infection, abdominal compartment syndrome, dehiscence, anastomotic leak, coagulopathy, deep vein thrombosis, fascial necrosis, ischemia/gastrointestinal necrosis, intestinal fistula, intestinal obstruction, pulmonary embolism and multiple organ failure ${ }^{20}$. The complication rates reported by Barker et al. are $15 \%^{11}$.

\section{A. C. System}

This system uses crosslinked polyurethane foam (PU) or polyvinyl alcohol (PVA), with pores of 400-600 micrometers, applied and held in place by an adhesive (Figure 3). A plastic film interface sits between the viscera and the foam, and adjusts the same to the edges of the lesion ${ }^{19,21}$. The foam is covered with adhesive, which is coupled to the skin with a margin of 3 to $5 \mathrm{~cm}$ from the wound. In this adhesive, a small hole of about $2 \mathrm{~cm}$ in diameter is created in the center and a TRAC TM-DAP adhesive (device leading the discharge to the reservoir) is coupled to it. Thus, the system connects to a pump (vacuum) generating continuous or intermittent subatmospheric pressure. The pressure is generally set at $125 \mathrm{mmHg}$ and distributed uniformly over the entire wound through the sponge pores ${ }^{19,21-23}$.

The vacuum-assisted closure is also known as negative pressure therapy, sub-atmospheric pressure or vacuum sealing technique. Argenta et al., in 1997, published an experimental work with the VAC system using acute wounds in pigs. In this work, they postulated that the VAC system has a multimodal mechanism of action ${ }^{19,24}$. Its effectiveness in severe traumatic wounds caused to evolve an area that belonged mainly to plastic and reconstructive surgery ${ }^{19}$.

The purpose of the VAC system is to remove the stagnant fluid and debris and to optimize the supply of blood and matrix deposition. Thus, the partial pressure of oxygen within the tissues increases and proliferation of bacteria is reduced. Also, there is a local increase of interleukin-8 and vascular endothelial growth factor, which may cause the accumulation of neutrophils and angiogenesis ${ }^{25}$.

The complications of VAC therapy are infrequent when the system is used correctly. The rates of most complications reported in the literature stem from previous co-morbidities of the patient and skin irritation by the adhesive use. Complications such as pain, bleeding and infection are more difficult to occur. Situations such as toxic shock syndrome, anaerobic sepsis, or thrombosis have also been described as a result of this technique, but are very rare ${ }^{21}$.

The total cost of VAC therapy is greater than that of other techniques. However, when analyzing the time involvement and costs with the nursing staff, there is a considerable reduction of the total cost. The advantage of comfort for patients is described in many studies as a relevant factor in choosing this therapy ${ }^{26}$.

\section{DISCUSSION}

The realization of laparostomy has been recommended since 1979. This technique allows extensive drainage of purulent secretion through the wall opening and also facilitates cleaning of the peritoneal cavity through scheduled or demand reoperations ${ }^{7}$. In this procedure, the abdominal wall plans are not completely approximated, allowing a regular inspection of intracavitary content. It can be used in the treatment of abdominal sepsis, abdominal compartment syndrome and damage control operationa ${ }^{7}$. The optimum technical requirements: protection of abdominal contents; prevention against evisceration; preservation of the fascia; minimal damage to the viscera; allowing to quantifying the loss of fluid to the third space; allow selective tamponade; minimize loss 
of domain; control the infection and inflammation and facilitate patient's management ${ }^{\text {. }}$.

\section{Comparison between the different techniques for damage control.}

Comparing the use of VAC to other methods, several studies have shown a better performance of this in relation to others. A prospective study conducted by Batacchi et al. ${ }^{27}$ in 2009 performed the comparison between abdominal trauma patients treated with Bogotá bags and the VAC technique during the temporary closing stage of the abdominal cavity. Treatment with VAC was more effective in better controlling intra-abdominal pressure $(p<0.01)$ and normalization of serum lactate $(p<0.001)$, as well as displaying shorter mechanical ventilation time, faster abdominal closure, and consequently lower time in the intensive care unit (ICU) and hospital. The scores' 'Sequential Organ Failure Assessment' (SOFA) and the mortality rate did not differ significantly.

Kaplan et al. ${ }^{6}$, in 2005, concluded that VAC is the technique that can meet the requirements of an ideal material for satisfactory temporary closure. The Bogotá technique showed $53 \%$ mortality, and the techniques of Barker and VAC displaied rates of 31 and $30 \%$, respectively. Regarding the occurrence of complications such as fistulas, the VAC technique presented a rate of $2.6 \%$, as opposed to $7 \%$ of the Barker technique and $13 \%$ of the Bogotá technique. The fascial closure was achieved in $79 \%$ of patients undergoing VAC, while in 58\% with the Barker technique and $18 \%$ with Bogotá technique ${ }^{6}$.

As for the control of intra-abdominal pressure (IAP), Batacchi et al. ${ }^{27}$, in 2009, compared the use of the Bogotá bag with the VAC system and concluded that the latter was more effective in controlling the IAP $(p<0.01)$ and lactate levels $(p<0.001)$ during the first 24 hours after surgical decompression. These patients had faster abdominal closure and discharge from ICU in less time, but mortality rates did not differ between the two groups.

Cheatham et al. ${ }^{20}$, in 2013, compared the use of VAC with the Barker technique, showing that both had similar rates of complications such as the development of abdominal compartment syndrome $(8 \%$ in both techniques) and fistulas (4\% in both techniques). The
VAC was associated with a primary fascial closing rate significantly higher at 30 days ( $73 \%$ versus $27 \%$ for the Barker technique) and lower mortality in the same period in patients who required open abdomen for at least 48 hours. Differences in mortality rates between the VAC and the Barker technique significantly increased during the first 30 days, due to the subsequent development of multiple organ failure in patients undergoing Barker technique due to better removal of rich peritoneal fluid cytokine (which increase organ dysfunction) at VAC.

Bruhin et al..$^{28}$, in a recent study comparing the various techniques through aspects such as contamination, fistula, mortality among others, obtained higher primary fascial closure rates after the use of VAC in combination with the technique of "dynamic closure" (mesh mediated traction, dynamic retention sutures or ABRATM) when compared with other techniques. In patients without contamination, this treatment resulted in a $81 \%$ closure, having been $72 \%$ with the exclusive use of VAC and $58 \%$ by the Barker technique. Data on the Bogotá bag technique were insufficient. In infected lesions, the combined technique resulted in the greater abdominal closure rate (74.6\%), followed by its exclusive use (48\%), by the Barker technique (35\%) and the Bogotá bag technique (27\%). Regarding the presence of fistulas and mortality rate, the VAC technique was the one with the lowest incidences.

\section{CONCLUSION}

The Bogotá bag technique was less efficient, but still is widely used due to its lower cost and greater ease of access to the material. The Barker technique may represent a reasonable cost alternative for patients who are subjected to damage control surgery for trauma, considering that $60 \%$ of cases will have the cavity closed after the first repproach. The VAC therapy was superior compared with other techniques, with greater control of the liquid of the third space, a lower rate of complications such as fistulas, lower mortality rates, lower rates of infection and greater ease in the primary closure of the abdominal cavity, and should be, whenever possible, the therapy of choice for the cases where one opts for maintaining laparostomy. 


\title{
R E S U M O
}

\begin{abstract}
A cirurgia de controle de danos, com ênfase em peritoneostomia, geralmente resulta em retração da aponeurose e perda da capacidade de fechar a parede abdominal, levando à formação de hérnias ventrais incisionais. Atualmente, várias técnicas oferecem maiores chances de fechamento da cavidade abdominal, com menor tensão. Deste modo, este estudo tem por objetivo avaliar três técnicas de fechamento temporário da cavidade abdominal: fechamento a vácuo (Vacuum-Assisted Closure Therapy - VAC), Bolsa de Bogotá e Vacuum-pack. Realizou-se uma revisão sistemática da literatura com seleção de 28 artigos publicados nos últimos 20 anos. As técnicas de Bolsa de Bogotá e Vacuum-pack tiveram como vantagem o acesso fácil ao material, na maioria dos centros, e baixo custo, ao contrário do que se observa na terapia a vácuo, VAC, que além de apresentar alto custo, não está disponível em grande parte dos hospitais. A técnica VAC, por outro lado, foi mais eficaz na redução da tensão nas bordas das lesões, ao remover fluidos estagnados e detritos, além de exercer ação a nível celular, aumentando as taxas de proliferação e divisão celular, e apresentou as maiores taxas de fechamento primário da cavidade abdominal.
\end{abstract}

Descritores: Abdome. Peritonite. Ferimentos e Lesões. Parede Abdominal. Infecção.

\section{REFERENCES}

1. Rotondo MF, Zonies DH. The damage control sequence and underlying logic. Surg Clin North Am. 1997(4);77(4):761-77.

2. Ferreira F, Barbosa E, Guerreiro E, Fraga GP, Nascimento Jr B, Rizoli S. Fechamento sequencial da parede abdominal com tração fascial contínua (mediada por tela ou sutura) e terapia a vácuo. Rev Col Bras Cir. 2013;40(1):85-9.

3. Maia DEF, Ribeiro Jr MAF. Manual de condutas básicas em cirurgia. In: Ribeiro Jr MAF, Gouveia NB, Santin S. Controle de danos. Santos: Roca; 2013. p.126-9.

4. Edelmuth RCL, Buscariolli YS, Ribeiro Jr MAF. Cirurgia para controle de danos: estado atual. Rev Col Bras Cir. 2013;40(2):142-51.

5. Torres Neto JR, Barreto AP, Prudente ACL, Santos AM, Santiago RR. Uso da peritoneostomia na sepse abdominal. Rev Bras Colo-Proctol. 2007;27(3):278-83.

6. Kaplan M, Banwell P, Orgill DP, Ivatury RR, Demetriades VD, Moore FA, et al. Guidelines for the management of the open abdomen. Dallas: HMP Communication; 2005.

7. Borráez AO. Abdomen abierto: la herida más desafiante. Rev Colomb Cir. 2008;23(4):204-9.

8. Ferraz ED, Vieira OM. Técnica de fechamento progressivo na laparostomia e descompressão abdominal. Rev Col Bras Cir. 2000;27(4):237-44.

9. Brock WB, Barker DE, Burns RP. Temporary closure of open abdominal wounds: the vacuum pack. Am Surg. 1995;61(1):30-5.

10. Kreis BE, de Mol van Otterloo AJ, Kreis RW. Open abdomen management: a review of its history and a proposed management algorithm. Med Sci Monit. 2013;19:524-33.

11. Rezende-Neto JB, Cunha-Melo JR, Andrade MV. Cobertura temporária da cavidade abdominal com curativo a vácuo. Rev Col Bras Cir. 2007;34(5):336-9.

12. Barker DE, Green JM, Maxwell RA, Smith PW, Mejia VA, Dart BW, et al. Experience with vacuum-pack temporary abdominal wound closure in 258 trauma and general and vascular surgical patients. J Am Coll Surg. 2007;204(5):784-92.

13. Smith LA, Barker DE, Chase CW, Somberg LB, Brock WB, Burns RP. Vacuum pack technique of temporary abdominal closure: a four-year experience. Am Surg. 1997;63(12):1102-7.

14. Navsaria PH, Bunting M, Omoshoro-Jones J, Nicol AJ, Kahn D. Temporary closure of open abdominal wounds by the modified sandwich-vacuum pack technique. Br J Surg. 2003;90(6):718-22.

15. Boele van Hensbroek P, Wind J, Dijkgraaf MG, Busch OR, Goslings JC. Temporary closure of the open abdomen: a systematic review on delayed primary fascial closure in patients with an open abdomen. World J Surg. 2009;33(2):199-207.

16. Cothren CC, Moore EE, Johnson JL, Moore JB, Burch JM. One hundred percent fascial approximation with sequential abdominal closure of the open abdomen. Am J Surg. 2006;192(2):238-42.

17. Miller RS, Morris Jr JA, Diaz Jr JJ, Herring MB, May AK. Complications after 344 damage-control open celiotomies. J Trauma. 2005;59(6):1365-71.

18. Barker DE, Kaufman HJ, Smith LA, Ciraulo DL, Richart $C L$, Burns RP. Vacuum pack technique of temporary abdominal closure: a 7-year experience with 
112 patients. J Trauma. 2000;48(2):201-6.

19. Banwell P, Téot L. Topical negative pressure (TNP): the evolution of a novel wound therapy. J Wound Care. 2003;12(1):22-8.

20. Cheatham ML, Demetriades D, Fabian TC, Kaplan MJ, Miles WS, Schreiber MA, et al. Prospective study examining clinical outcomes associated with a negative pressure wound therapy system and Barker's vacuum packing technique. World J Surg. 2013;37(9):2018-30.

21. Leijnen $M$, Steenvoorde $P$, vanDoorn $L$, da Costa SA, Oskam J. Does VAC increase the risk of venous thromboembolism? J Wound Care. 2007;16(5):2112.

22. Labler L, Keel M, Trentz O, Heinzelmann M. Wound conditioning by vacuum assisted closure (V.A.C.) in postoperative infections after dorsal spine surgery. Eur Spine J. 2006; 15(9):1388-96.

23. Milcheski DA, Zampieri FMC, Nakamoto HA, Tuma Jr P, Ferreira MC. Terapia por pressão negativa na ferida traumática complexa do períneo. Rev Col Bras Cir. 2013;40(4):312-7.

24. Argenta LC, Morykwas MJ. Vacuum-assisted closure: a new method for wound control and treatment: clinical experience. Ann Plast Surg. 1997;38(6):56376; discussion 577.

25. Wang W, Pan Z, Hu X, Li Z, Zhao Y, Yu AX. Vacuum-assisted closure increases ICAM-1, MIF, VEGF and collagen I expression in wound therapy. Exp Ther Med. 2014;7(5):1221-6.

26. Braakenburg A, Obdeijn $M C$, Feitz $R$, van Rooij IA, van Griethuysen AJ, Klinkenbij JH. The clinical efficacy and cost effectiveness of the vacuum-assisted closure technique in the management of acute and chronic wounds: a randomized controlled trial. Plast Reconstr Surg. 2006;118(2):390-7.

27. Batacchi S, Matano S, Nella A, Zagli G, Bonizzoli $M$, Pasquini $A$, et al. Vacuum-assisted closure device enhances recovery of critically ill patients following emergency surgical procedures. Crit Care. 2009;13(6):R194.

28. Bruhin A, Ferreira F, Chariker M, Smith J, Runkel N. Systematic review and evidence based recommendations for the use of negative pressure wound therapy in the open abdomen. Int J Surg. 2014;12(10):1105-14.

Received in: 31/03/2016

Accepted for publication: 16/06/2016

Conflict of interest: none.

Source of funding: none.

\section{Mailing address:}

Emily Alves Barros

E-mail: ab_emily@hotmail.com 